\title{
Method for size optimisation of large wind-hydrogen systems with high penetration on power grids
}

\author{
M. Beccali*, S. Brunone, P. Finocchiaro, J.M. Galletto \\ Dipartimento dell'Energia, Università degli Studi di Palermo, Viale delle Scienze, Bldg 9, 90128 Palermo, Italy
}

\section{H I G H L I G H T S}

- Electric grids with high wind penetration levels have operational problems.

- Hydrogen production and storage can mitigate impact on grids of wind farms.

- The study describes an optimisation method for analysing wind-hydrogen systems.

- Optimal size of the hydrogen plant gives the minimum hydrogen production cost.

- The minimum hydrogen production cost does not give the maximum peak shaving effect.

\section{A R T I C L E I N F O}

\section{Article history:}

Received 21 January 2012

Received in revised form 22 June 2012

Accepted 4 August 2012

Available online $\mathrm{xxxx}$

\section{Keywords:}

Hydrogen

Wind energy

Wind-hydrogen system

Electrolysis

Energy storage

\begin{abstract}
A B S T R A C T
Wind power generation is growing rapidly in many locations around the world. Power systems are able to absorb large amounts of wind capacity, but operational problems arise when the wind power penetration becomes high. Such factors as voltage dips, frequency variations, low power system stability, low reactive power and power flow imbalances reduce the economic value and represent a barrier to the unlimited development of wind energy. Hydrogen production from wind power that is not matched with hourly electricity demand appears to be an attractive storage option capable of providing a balancing service to the electricity generators and suppliers for mitigation of the negative impacts due to the random nature of wind. Because of its multi-functionality, hydrogen can be used directly as a fuel, mixed with methane, or transmitted through pipelines to the users. The aim of this paper is to produce useful suggestions for the planning, development and sizing of wind-hydrogen systems by taking into account the local and regional resources, demands, constraints and opportunities. This study considers both the economic and technological variables and describes an optimisation method (OM) for analysing power systems in which part of the electricity generated by a grid-connected wind plant is used to produce hydrogen by electrolysis. An example application of this OM has been developed for a specific geographical area located in central Sicily. Our results identify the potential and the limitations connected to cases that use excess wind power to produce hydrogen for civil applications.
\end{abstract}

(c) 2012 Elsevier Ltd. All rights reserved.

\section{Introduction}

The addition of wind power to power generation systems reduces the amount of environmentally hazardous emissions created by electricity production and decreases the operational costs of the power system because less fuel is consumed in conventional power plants. Wind power also adds a capacity value to the power system [1].

However, wind power increases variability and uncertainty in power systems, which can induce potential impacts on the

\footnotetext{
* Corresponding author. Tel.: +39 09123861911; fax: +39 091484425 .

E-mail address: marco.beccali@dream.unipa.it (M. Beccali).
}

reliability and efficiency levels. In principle, these impacts can be either positive or negative [2].

The negative impacts that wind power may have on a power system would not offset the benefits of incorporating wind energy into the system. The disadvantages of incorporating wind power can be local (voltage dips, frequency variations and low power factors) and wide-scale (lower power system stability, lower reactive power/voltage control and power flow imbalances) $[1,3,4]$.

Electrical systems with high wind penetration levels contain operational problems that reduce the economic value of wind energy and present a barrier to the unlimited development of wind energy. The introduction of such new technologies and strategies as forecasting, geographical dispersion, interconnections to neighbouring systems and sophisticated power electronics will mitigate 
these problems. However, because these strategies cannot completely mitigate the random nature of wind, the large-scale use of wind power will ultimately require uptake via energy storage. Because of its multi-functionality, hydrogen represents an attractive storage option with the ability to provide a balancing source for electricity generators and suppliers $[5,6]$.

The hydrogen produced from electricity generated by gridconnected wind power plants may be used in a variety of ways: it can be used directly as a fuel, mixed with methane, transmitted through pipelines to users, or used to enhance the performance of the wind turbines and match their output with the user expectations [7].

Wind-hydrogen generation has been previously studied by several authors.

Korpås and Greiner [8] have developed a logistic simulation model to evaluate the performance of the wind-hydrogen plants. Their project analysed a case study that simulates the use of excess wind power in a weak distribution grid to produce $\mathrm{H}_{2}$ for vehicles. Their results show that introducing electrolytic $\mathrm{H}_{2}$ production as a controllable load can significantly increase the penetration of wind power in an electrical power system.

Mantza and De Battista [9] have investigated the control requirements necessary to simultaneously achieve the grid and electrolyser specifications in a wind-hydrogen energy system by exploiting the idle generation capacity of modern wind turbines to produce hydrogen.

Jørgensen and Ropenus [10] performed a study using four different wind penetration scenarios to investigate the production price of hydrogen from grid-connected electrolysis in the West Danish electricity system. The results from their study yielded estimations of a minimum hydrogen price of $0.41-0.45 € / \mathrm{Nm}^{3}$ (32$35 € / G J)$, which is significantly higher than the suggested DOE milestone of $18 \$ / G J$ for 2015.

Shaw and Peteves [11] used a cost-benefit approach to evaluate the final impact on the end-consumer of using the wind-hydrogen systems. This group concluded that exploiting the synergies in the European hydrogen and wind sectors through a Europe-wide wind-hydrogen strategy has the potential to enhance the prospects for commercialisation of the renewable electrolytic hydrogen pathway in the short-term.

Linnemann and Steinberger-Wilckens [12] have studied two different wind-hydrogen systems and analysed the ensuing cost of hydrogen per unit of energy service. This group investigated two hydrogen generation plants: a small $(305 \mathrm{~kW})$ decentralised installation and a large (297 MW) plant. Their results showed that the total hydrogen cost (including the German petrol tax and the VAT) of the small plant was more than two times the total hydrogen cost of the larger plant. They also calculated the order of magnitude between internal and external costs of gasoil and hydrogen production in the large-scale installation as referenced against the total fuel cost of vehicles per $100 \mathrm{~km}$ of travel. They found that the ratio between the internal costs of hydrogen and gasoil has a factor of 3 . This ratio is reduced to a factor of 2 , approximately, if the total (internal + external) cost is considered.

Greiner et al. [13] have developed a method for assessing the wind-hydrogen energy systems that enables optimised component sizing and calculation of $\mathrm{H}_{2}$ cost. This method was applied to a case study on a Norwegian island. The sensitivity analyses showed that a marginal decrease in the wind turbine and electrolyser cost could reduce the $\mathrm{H}_{2}$ cost substantially in both the gridconnected and isolated systems.

Pelacchi and Poli [14] have proposed the use of hydrogen storage as a feasible policy for adoption in real-time by the Independent System Operator (ISO) to maintain a certain level of reliability within the hydro-thermoelectric systems. In a case study calibrated on the electric power system of one of the largest Italian islands, they found that the installation of a plant for hydrogen production and storage becomes convenient as soon as the installed wind capacity exceeds $10 \%$ of the peak load.

Bernal-Agustín and Dufo-López [15] compared several windhydrogen systems (composed of wind turbines, a compressor, a hydrogen tank and a fuel cell) to wind-only systems. They concluded that "for the wind-hydrogen systems to have a similar profitability as the wind-only systems, the selling price of the electricity generated by the fuel cell would need to be very high: $171 \mathrm{c} € / \mathrm{kW}$ h for (...) the current situation and (...) about $43 \mathrm{c} € /$ $\mathrm{kWh}$ for the best future scenarios, in which the cost of the hydrogen components is about $5 \%(\ldots)$ of today's costs (...) and the electricity-hydrogen-electricity conversion is outstandingly better than current standards".

Gutiérrez-Martìn et al. [16] have studied a Spanish wind farm, placed in the northwest region, with a capacity of $48.8 \mathrm{MW}$ which generates $18.4 \%$ of the surplus electricity that cannot be evacuated through the node during the off-peak hours. The authors have analysed and optimised an electricity-powered hydrogen production system to manage this surplus energy. They calculated a hydrogen production of $13 \mathrm{GW}$ h per year, which can be used to produce peak electricity using a stationary fuel cell, thus raising the power of the hybrid system to $54.8 \mathrm{MW}$.

Rodrìguez et al. [17] have analysed the potential for hydrogen production from wind resources in the province of Córdoba, the second consumer of fossil fuels for transportation in Argentina. They concluded that the single department of Rìo Cuarto has, by itself, the potential to provide 10 times the hydrogen amount required for vehicular transportation in the entire province.

Finally, Troncoso and Newborough [18] assert that deploying an electrolysis plant next to a new wind power plant to generate "green" industrial hydrogen from curtailed energy will provide an economically justifiable pathway for expanding onshore wind up to a penetration of $100 \%$.

\section{Description of the optimisation method}

The objective of this study is to give useful suggestions for the planning, development and sizing of wind-hydrogen power systems by taking into account the local and regional resources, demands, constraints and opportunities.

The study considers both the economic and technological variables and describes an optimisation method (OM) for analysing power systems in which part of the electricity generated by a grid-connected wind plant is used to produce hydrogen by electrolysis.

The basic concept is the use of an electrolyser to shave the output peaks from the wind farm when the power generation exceeds a given end-user demand.

An exemplary application of this OM has been developed for a specific geographical area located in central Sicily. The results from this investigation allowed us to identify the potential and the limitations connected to the use of excess wind power to produce hydrogen for civil applications.

The OM requires the following minimum set of input data:

A. Wind resource available on site (the monthly average wind speeds or the wind potential).

B. Wind plant specifications (the power curves for wind turbines).

C. Electrical load (the annual consumption).

D. Electrolyser specifications (the efficiency).

E. Cost of devices (the capital, replacement and operating costs). 
For a given nominal power from a wind plant, the OM follows these steps:

1. Electrical load and wind resources are modelled (e.g., with the HOMER tool).

2. A value of the electrolyser-rated power is fixed.

3. The annual hydrogen production according to the available wind energy surplus is calculated.

4. The gas compression and storage sections are sized by an optimisation loop.

5. The hydrogen production cost is calculated according to the annual costs and revenues.

6. Steps 1-4 are repeated for a total of 15-20 values of the electrolyser-rated power.

7. A hydrogen production cost curve (with electrolyser-rated power on the $x$-axis) is drawn.

The minimum point of the hydrogen production cost curve yields the optimal size of the electrolyser and consequently of the gas compression and storage units.

The level of detail of the analysis increases as further information is added and as the analysis becomes more accurate.

The OM proposed in this paper can be applied to different "wind energy penetration levels" in an electricity network area. "Wind energy penetration level" (WP) can be defined as the percentage

Table 1

Cases and sub-cases.

\begin{tabular}{ll}
\hline Case 1 & $\begin{array}{l}\text { A - Hydrogen system includes a compressed gas } \\
\text { storage unit and oxygen is not handled and sold }\end{array}$ \\
$\mathrm{H}_{2}$ for transportation & $\begin{array}{l}\text { B - Hydrogen system includes a compressed gas } \\
\text { storage unit and oxygen is handled and sold } \\
\text { C - Hydrogen system does not include any storage } \\
\text { unit and oxygen is not handled and sold } \\
\text { D - Hydrogen system does not include any storage } \\
\text { unit and oxygen is handled and sold } \\
\text { Case } 2 \\
\text { A - Hydrogen system includes a compressed gas } \\
\text { storage unit and oxygen is not handled and sold } \\
\text { B - Hydrogen system includes a compressed gas } \\
\text { storage unit and oxygen is handled and sold }\end{array}$ \\
\hline
\end{tabular}

of the electrical energy produced by wind generation in the electrical system on an annual basis.

The main assumption of this study is the consideration of hydrogen production and storage as a strategy to mitigate the negative impacts on the electrical system due to wind farm operation. Hydrogen produced by the electrolyser is used in two alternative ways: as the fuel for vehicles (Case 1) or as a method for production of electricity for stationary uses via recombination with air in a fuel-cell system (Case 2). These two alternative uses have been split into four and two sub-cases (Table 1 ), respectively, according to further assumptions regarding the $\mathrm{O}_{2}$ use (sold or discarded) and whether or not $\mathrm{H}_{2}$ storage devices are present. These cases are also shown schematically in Figs. 1 and 2.

In Cases 1 and 2, a Power Conditioning and Controls (PCCs) unit manages the power flows among the multiple energy providers (the wind plant, the grid and the fuel cell) and the users (electricity end-users and the electrolyser).

The PCC unit includes a power regulator for matching of the electrolyser polarisation curve (Case 1 and Case 2) and the fuel-cell characteristic curve (Case 2) at any power level with minimum conversion losses.

In Case 1, the PCC unit directs the power from the wind turbines to the end-users and adds grid power when there is not enough power from the wind farm. When the wind power generation exceeds the end-user demand, the PCC unit directs the excess power from the wind turbines to the electrolyser to produce hydrogen and storage of energy, thus avoiding grid overloads.

In Case 2, the PCC unit directs the power from the wind turbines to the end-users and adds sequenced fuel-cell power and grid power when there is not enough power from the wind farm. When the wind power generation exceeds the end-user demand, the PCC unit directs the excess power from the wind turbines to the electrolyser to produce hydrogen.

The total surplus of wind energy includes the energy effectively fed into the electrolyser and the two fractions that cannot be used for hydrogen production: the power exceeding the electrolyserrated power and the power lower than the electrolyser idling power (assumed equal to $20 \%$ of the stack-rated power) [19,20].

The entire wind-hydrogen grid-integrated system analysed in this study has been modelled within the TRNSYS platform [21]. The Wind Energy Conversion System (WECS), the power

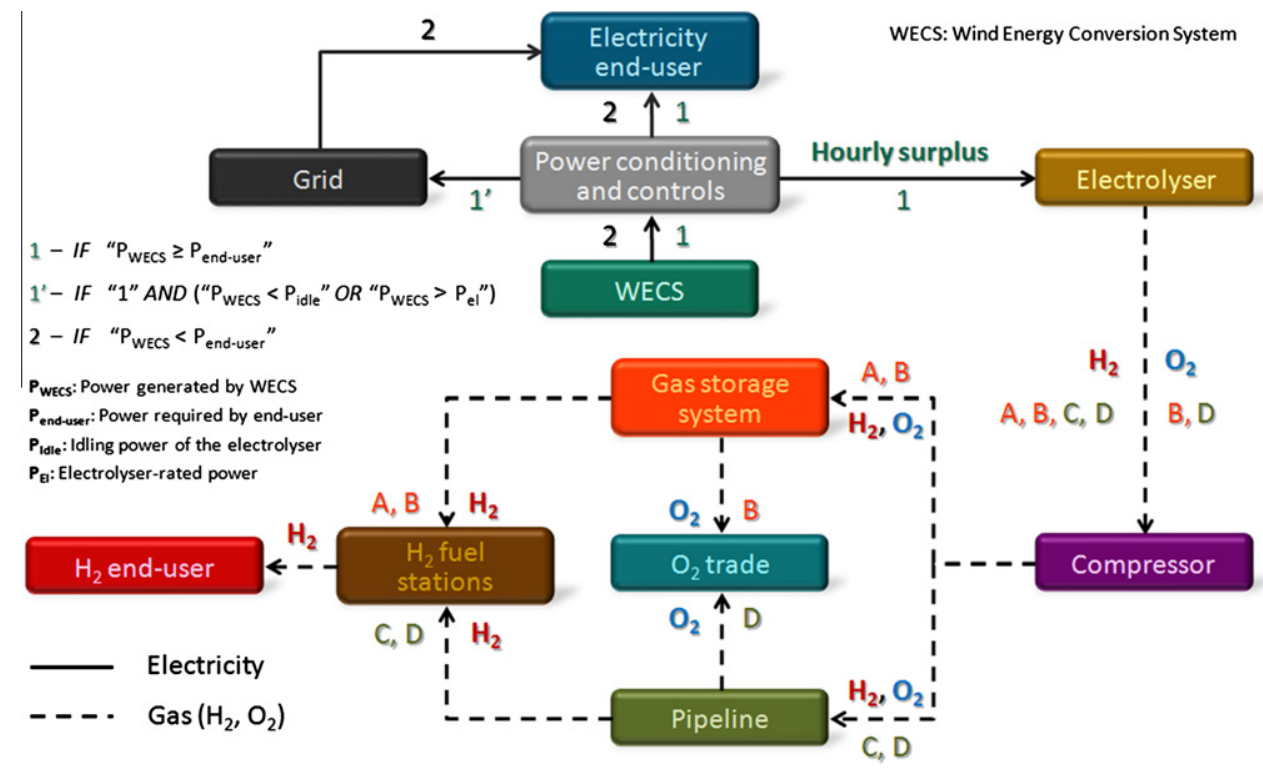

Fig. 1. Schematic of Case 1 and relative sub-cases (A-D). 


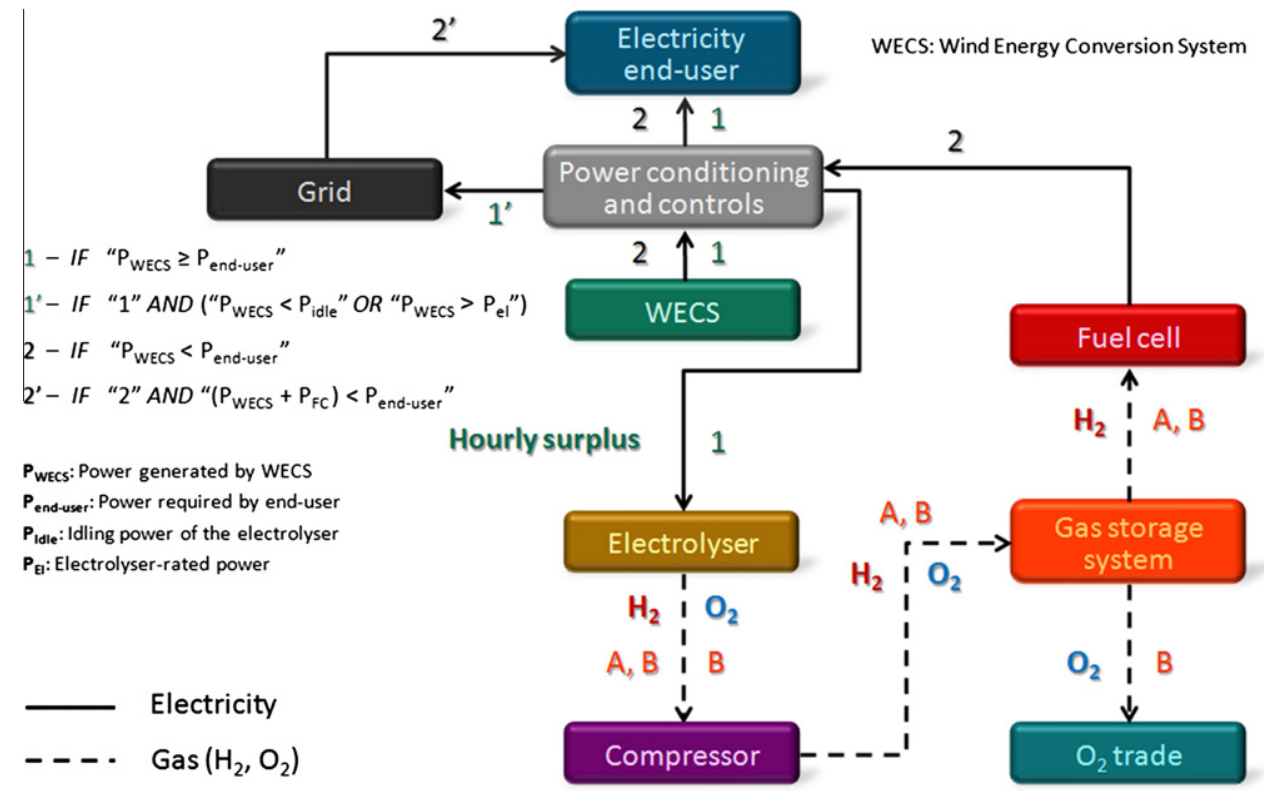

Fig. 2. Schematic of Case 2 and relative sub-cases (A and B).

conditioning unit, the AC-busbar, the electrolyser, the compressed gas storage system, the multi-stage compressor and the fuel-cell system have been modelled using the types contained in the HYDROGEMS library [21]. The economic analysis has been carried out using the economic model implemented in NREL's HOMER simulation tool [22].

Each value of the electrolyser-rated power analysed in this study designates a single simulation session carried out with TRNSYS. Each simulation session includes several runs; each run represents a step in an iterative optimisation process that determines the gas compression and storage unit sizes (step 3 of the OM). The annual hydrogen production and surplus wind energy are two major outputs that are not altered within a single simulation session. The annual costs and revenues are calculated with the economic model implemented in HOMER using the following data: the system component specific costs, oxygen selling price, electricity rates, real annual interest rate and project lifetime.

\section{Economics of wind- $\mathrm{H}_{2}$ systems: basic assumptions}

The cost of the hydrogen production was the key economic parameter chosen for size optimisation of the hydrogen production devices and storage devices and is expressed as:

Hydrogen production cost

$C_{\mathrm{H}_{2}}=\frac{C_{\mathrm{ann}, \mathrm{tot}}}{Q_{\mathrm{H}_{2}}}$

$C_{\mathrm{ann}, \text { tot }}$ is the total annualised cost (i.e., the algebraic sum of the annual costs and revenues associated with each system component

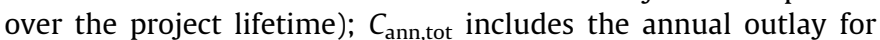
electricity and, when available, the revenue from electrolytic oxygen sales; and $Q_{\mathrm{H}_{2}}$ is the annual amount of hydrogen production [22].

The annual cost of a component is equal to its annual operating cost plus its capital and replacement costs annualised over the project lifetime. We performed a preliminary economic survey to assess how the specific capital costs of the electrolyser, the compressed gas storage system and the multi-stage compressor vary according to the sizes of the devices. Our results are based on many Refs. [13,23-40] and are graphically shown in Figs. 3-5.

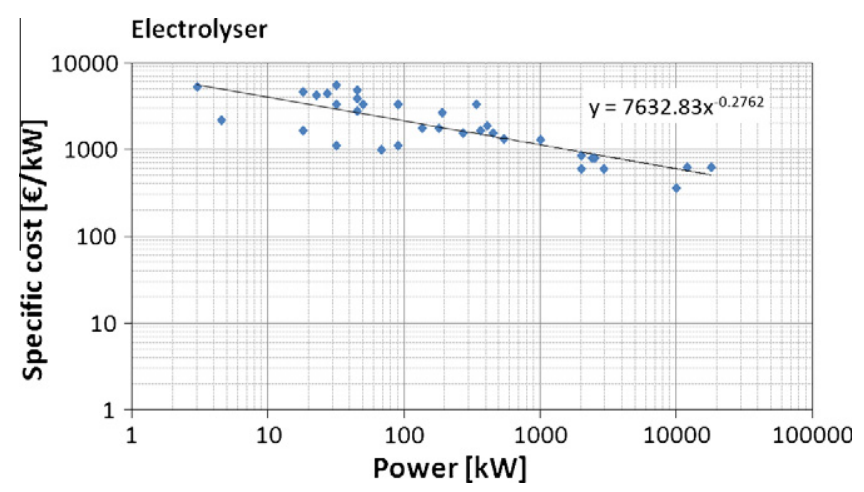

Fig. 3. Electrolyser-specific capital costs.

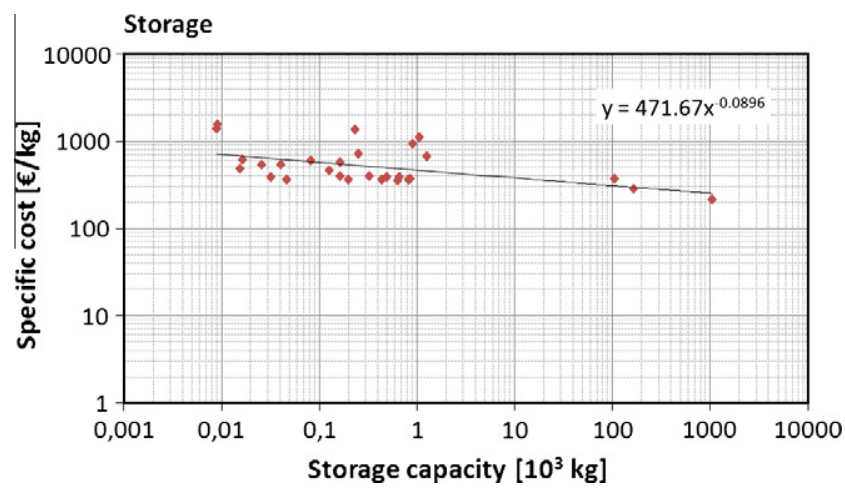

Fig. 4. Compressed gas storage system-specific capital costs.

We assumed that the replacement costs were equal to the capital costs, whereas annual operating costs (Table 2 ) have been fixed according to a literature review [6,13,23-25,36,41-43].

The results of a survey investigating the lifetimes of hydrogen production and storage devices are shown in Table 3, and the economic parameters of WECS are presented in Table 4. 


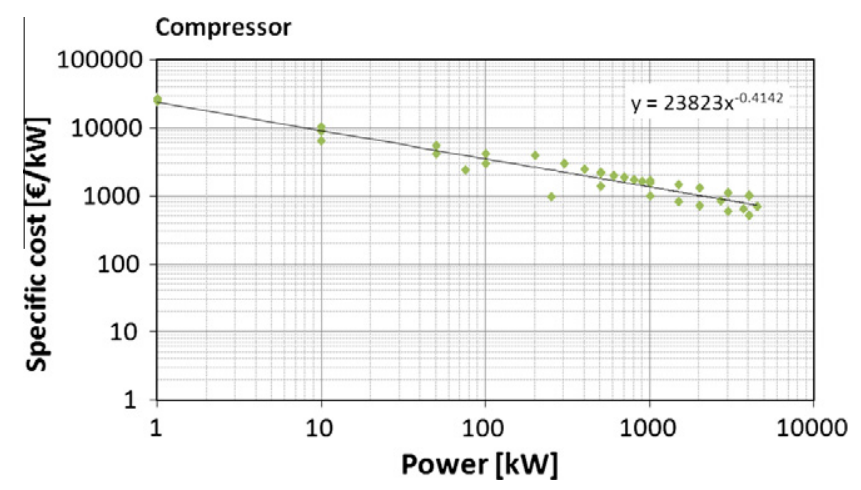

Fig. 5. Compressor-specific capital costs.

Finally, we assumed a real annual interest rate of $6 \%$, a project lifetime of $25 \mathrm{yr}$, an oxygen selling price of $2 € / \mathrm{Nm}^{3}$ [46] and two electricity rates: $0.04 € / \mathrm{kW}$ h to remunerate the surplus wind energy used to produce hydrogen and $0.10 € / \mathrm{kW}$ h to purchase electricity for the compressors and for the electrolyser operation in standby mode (i.e., in which a polarisation current is commonly applied to protect the electrodes from corrosion).

\section{Application to a regional context}

The wind resource and the electrical load of a given area in central Sicily were managed by means of HOMER. We also assumed the use of Vestas v52 $(850 \mathrm{~kW})$ turbine typology.

The electrolyser efficiency was calculated for each time step and for each run included in the simulation sessions carried out with TRNSYS. The value of the efficiency varies according to the load factor of the electrolyser.

In this context, the electrical load was referenced to a 20,000 person community located in a mountainous region near Enna, Sicily. We first established a base annual load-profile resulting from the time combination of six typical days (cool, intermediate and hot days, evenly subdivided into working days and holidays). The typical daily load profiles were defined by using the statistical data contained in Refs. $[47,48]$ and by making several assumptions regarding the consumption associated with a single-family unit. Subsequently, we imported the base annual load-profile into HOMER. We applied an hourly noise (10\%) to add randomness to the load data (Figs. 6 and 7).

The wind resource modelling followed a similar procedure. We entered 12 average wind speed values, one for each month of the year (Table 5) and defined four advanced parameters: the Weibull shape factor, the autocorrelation factor, the diurnal pattern strength and the hour of peak wind speed (Table 6). The Weibull shape factor is a measure of the distribution of wind speeds throughout the year. The autocorrelation factor is a measure of
Table 3

Lifetime of hydrogen production and storage devices.

\begin{tabular}{|c|c|c|c|c|c|}
\hline \multicolumn{2}{|c|}{ Electrolyser } & \multicolumn{2}{|c|}{ Compressed gas storage } & \multicolumn{2}{|c|}{ Compressor } \\
\hline (yr) & Source & (yr) & Source & (yr) & Source \\
\hline 20 & [6] Gonzàlez & 30 & [13] Greiner & 10 & [13] Greiner \\
\hline 15 & [13] Greiner & 30 & [23] ALTENER & 10 & [23] ALTENER \\
\hline 20 & [23] ALTENER & 22 & [31] Howes & 22 & [31] Howes \\
\hline 5 & [32] Padrò & & & & \\
\hline 20 & [44] Smith & & & & \\
\hline 10 & [45] Levene & & & & \\
\hline \multicolumn{6}{|c|}{ Values used in the study } \\
\hline $15 \mathrm{yr}$ & & $25 \mathrm{yr}$ & & $15 \mathrm{yr}$ & \\
\hline
\end{tabular}

Table 4

Economic parameters of WECS $[13,21,22,40]$

\begin{tabular}{lll}
\hline Capital cost $(€ / \mathrm{kW})$ & Annual operating cost $(\%$ cap. cost $)$ & Lifetime $(\mathrm{yr})$ \\
\hline 1000 & 2 & 20 \\
\hline
\end{tabular}

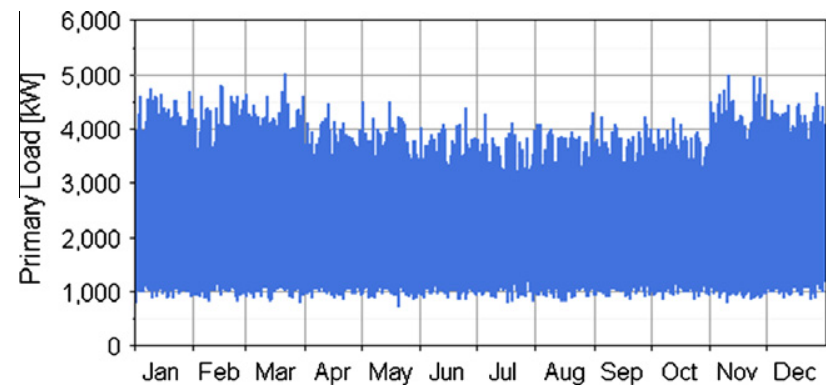

Fig. 6. Annual electricity demand (20460 MW h/yr).

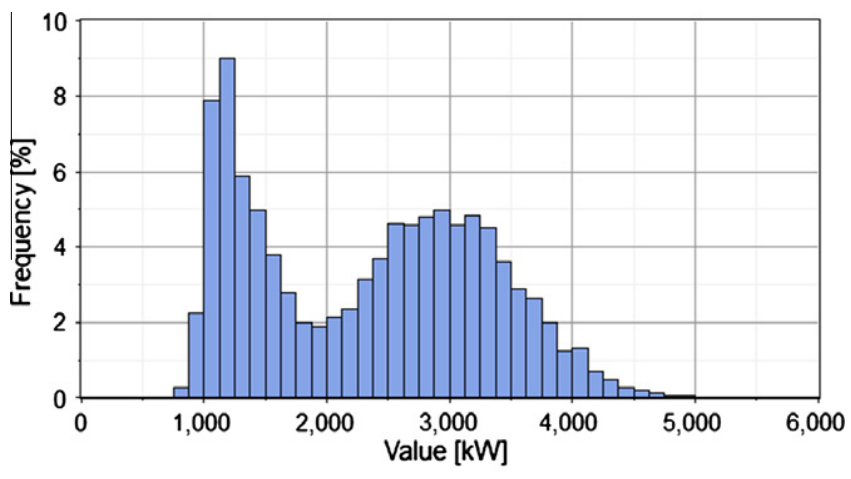

Min $=733 \mathrm{~kW} \quad$ Max $=5,032 \mathrm{~kW} \quad$ Average $=2,336 \mathrm{~kW} \quad$ Median $=2,446 \mathrm{~kW}$

Fig. 7. Probability density function of the annual electricity demand.

Table 2

Annual operating costs

\begin{tabular}{|c|c|c|c|c|c|}
\hline \multicolumn{2}{|l|}{ Electrolyser } & \multicolumn{2}{|c|}{ Compressed gas storage } & \multicolumn{2}{|l|}{ Compressor } \\
\hline (\% cap. cost) & Source & (\% cap. cost) & Source & (\% cap. cost) & Source \\
\hline 3 & [6] Gonzàlez & 2.0 & [13] Greiner & 4 & [13] Greiner \\
\hline 4 & [13] Greiner & 0.5 & [23] ALTENER & & \\
\hline 2 & [23] ALTENER & 0.2 & [36] Amos & & \\
\hline 3 & [24] Mann & 2.3 & [42] Cotrell & & \\
\hline 3 & [25] Berry & & & & \\
\hline 6 & [41] Da Silva & & & & \\
\hline 7 & [42] Cotrell & & & & \\
\hline
\end{tabular}

Values used in the study 
Table 5

Average wind speeds in Enna [47].

\begin{tabular}{llll}
\hline Average wind speed $(\mathrm{m} / \mathrm{s})$ & & \\
\hline January & 6.16 & July & 4.19 \\
February & 6.39 & August & 4.27 \\
March & 6.03 & September & 5.14 \\
April & 6.19 & October & 5.42 \\
May & 5.11 & November & 6.15 \\
June & 4.89 & December & 6.53 \\
\hline
\end{tabular}

Table 6

Advanced statistical parameters.

\begin{tabular}{ll}
\hline Weibull shape factor $(k)$ & 1.83 \\
Autocorrelation factor & 0.85 \\
Diurnal pattern strength & 0.3 \\
Hour of peak wind speed & 15 \\
\hline
\end{tabular}

how strongly the wind speed in $1 \mathrm{~h}$ depends on the wind speed in the preceding hour. The diurnal pattern strength and the hour of peak wind speed indicate the magnitude and the phase, respectively, of the average daily pattern of the wind speed [50].

The Weibull shape factor is taken from Ref. [49], whereas the values of the other advanced statistical parameters are within the typical ranges reported in [51].

After entry the input data reported in Tables 5 and 6, HOMER generated the synthetic hourly data composed of a set of 8760 values of the wind speed (one for each hour of the year), as shown in Fig. 8.

According to the A, B and C input data (see paragraph, "Description of the optimisation method"), different WPs can occur. In this study, we investigated four WP values: $22 \%, 41 \%, 59 \%$ and $75 \%$. These values were generated by varying the number of installed turbines chosen with the same typology (Vestas v52-850 kW). In other words, we changed the number of generators instead of their power curves to vary the installed wind power. The amount of the installed wind power required for each of the analysed WPs is displayed in Table 7.

The installed wind power capacity increases more rapidly than its corresponding WP value because the wind speed varies ran-

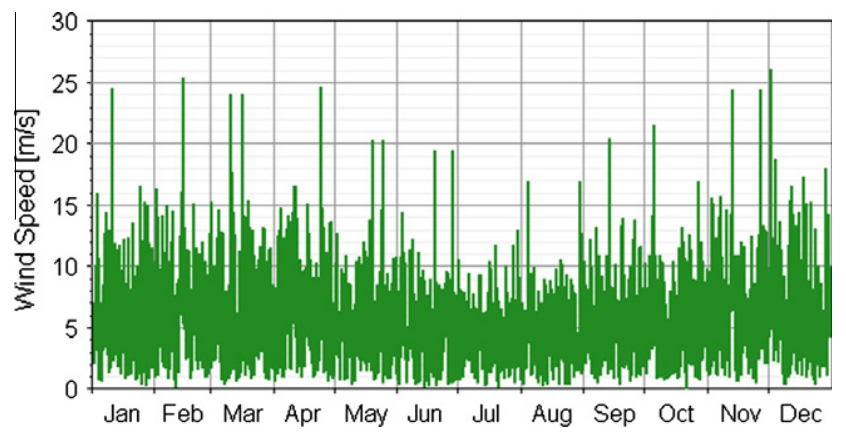

Fig. 8. Wind speed annual time-profile.

Table 7

Variation of installed wind power with WP.

\begin{tabular}{llc}
\hline Peak power demand (MW) & 5.032 & \\
& N. turbines $(850 \mathrm{~kW})$ & Installed power $(\mathrm{MW})$ \\
\hline $22 \%$ & 2 & 1.70 \\
$41 \%$ & 4 & 3.40 \\
$59 \%$ & 9 & 7.65 \\
$75 \%$ & 21 & 17.85 \\
\hline
\end{tabular}

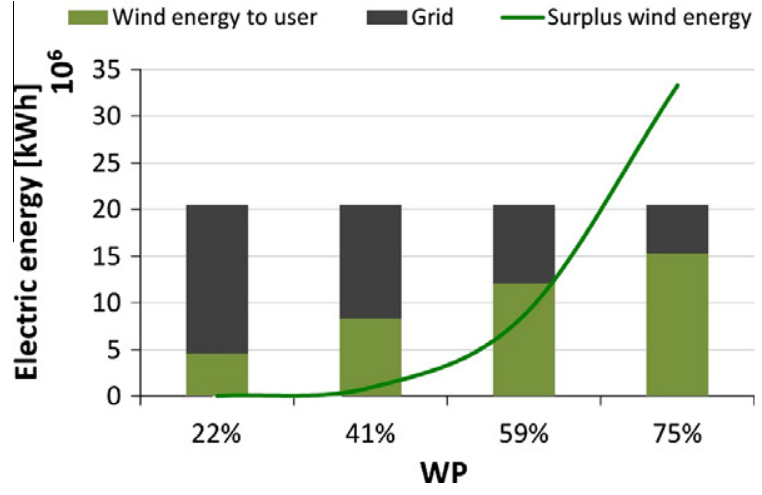

Fig. 9. Contributions to the total electricity demand.

domly, which means that the wind power peaks rarely overlap the electric demand peaks. Consequently, the surplus wind energy increases rapidly with its corresponding WP value (Fig. 9).

The gas compression and storage unit sizes have been determined by an iterative optimisation process implemented directly in TRNSYS. This process requires knowledge of both hydrogen production and demand on an hourly basis. The annual hydrogen demand has been estimated as equal to the annual hydrogen production.

The purpose of the iterative process is to identify the size of the hydrogen storage unit with a maximum pressure level of 0.9 over a simulation run. Once the capacity of the storage unit is optimised, the compressor-rated power is fixed according the corresponding peak power consumption.

A single iterative optimisation process requires an average of 3-4 simulation runs. Because we investigated approximately 200 values of the electrolyser-rated power, the entire study required more than 500 simulation runs.

The amount of hydrogen produced by the electrolysis depends on the amount of surplus wind energy available and the efficiency of the electrolysis process. Both the surplus wind energy and the rated power affect the capacity factor of the electrolyser.

The capacity factor is an index of the productivity of the electrolyser, and Table 8 contains a summary of the annual hydrogen production.

All previous results are general and are not influenced by the choice of options regarding the use of the $\mathrm{H}_{2}$ and $\mathrm{O}_{2}$ produced by the plant. Additional details on the analysis of these alternatives are reported in the following sub-sections.

\subsection{Case 1 - Hydrogen for transportation}

In reference to the analytical methodology described in the last section (step 2 of the OM) and in addition to the annual hydrogen production, we also estimated the oxygen annual production, which represents a key output of sub-cases B and D.

The storage section was sized only for sub-cases A and B. Subcase $B$ also included an oxygen storage unit in addition to the hydrogen storage unit. We assumed a maximum allowable pressure of 400 bar for both the hydrogen and oxygen storage units and a constant time profile for the annual hydrogen and oxygen demand.

The compression devices were required in all of the sub-cases. In sub-cases $\mathrm{A}$ and $\mathrm{B}$, the compressors had a maximum discharge pressure (m.d.p.) of 400 bar, whereas in sub-cases $C$ and $D$, the compressors had an m.d.p. of 20 bar (in sub-cases C and D, we assumed that the gases from the electrolyser were directly pumped into a piping system with an operating pressure of 20 bar). 
Table 8

Summary of the annual hydrogen production.

\begin{tabular}{|c|c|c|c|c|c|c|c|}
\hline \multicolumn{8}{|l|}{ WP } \\
\hline \multicolumn{2}{|l|}{$22 \%$} & \multicolumn{2}{|l|}{$41 \%$} & \multicolumn{2}{|l|}{$59 \%$} & \multicolumn{2}{|l|}{$75 \%$} \\
\hline$P_{\text {Electr. }}(\mathrm{kW})$ & $\mathrm{H}_{2}$ production $\left(\mathrm{Nm}^{3} / \mathrm{yr}\right)$ & $P_{\text {Electr. }}(\mathrm{kW})$ & $\mathrm{H}_{2}$ production $\left(\mathrm{Nm}^{3} / \mathrm{yr}\right)$ & $P_{\text {Electr. }}(\mathrm{kW})$ & $\mathrm{H}_{2}$ production $\left(\mathrm{Nm}^{3} / \mathrm{yr}\right)$ & $P_{\text {Electr. }}(\mathrm{kW})$ & $\mathrm{H}_{2}$ production $\left(\mathrm{Nm}^{3} / \mathrm{yr}\right)$ \\
\hline 10 & 457 & 30 & 7745 & 90 & 62,937 & 200 & 212,435 \\
\hline 20 & 1009 & 60 & 15,460 & 180 & 124,415 & 400 & 417,423 \\
\hline 40 & 2046 & 120 & 29,807 & 360 & 243,919 & 1000 & 985,764 \\
\hline 100 & 4766 & 300 & 68,078 & 900 & 571,482 & 2000 & $1,822,300$ \\
\hline 125 & 5697 & 400 & 86,431 & 1350 & 814,580 & 3000 & $2,573,200$ \\
\hline 150 & 6610 & 500 & 102,400 & 1800 & $1,035,100$ & 4000 & $3,249,900$ \\
\hline 175 & 7473 & 600 & 115,484 & 2250 & $1,232,600$ & 5000 & $3,864,100$ \\
\hline 200 & 8244 & 700 & 127,551 & 2700 & $1,404,500$ & 6000 & $4,422,400$ \\
\hline 225 & 8950 & 800 & 138,167 & 3600 & $1,671,700$ & 8000 & $5,402,600$ \\
\hline 250 & 9564 & 900 & 147,275 & 4500 & $1,820,200$ & 10,000 & $6,193,400$ \\
\hline 275 & 10,172 & 1200 & 173,408 & 4950 & $1,857,400$ & 11,000 & $6,522,800$ \\
\hline 300 & 10,597 & 1500 & 190,504 & 5400 & $1,886,200$ & 12,000 & $6,800,400$ \\
\hline 400 & 12,060 & 1650 & 196,288 & 5850 & $1,900,300$ & 13,000 & $7,017,100$ \\
\hline 450 & 12,414 & 1800 & 199,934 & 6300 & $1,910,500$ & 14,000 & $7,125,500$ \\
\hline 500 & 12,494 & 1950 & 202,228 & 7200 & $1,922,300$ & 16,000 & $7,217,900$ \\
\hline 550 & 12,565 & 2100 & 202,743 & 8100 & $1,929,800$ & 18,000 & $7,262,300$ \\
\hline 600 & 12,478 & 2400 & 205,890 & 9000 & $1,935,600$ & 20,000 & $7,292,200$ \\
\hline 800 & 12,346 & 2700 & 205,993 & & & & \\
\hline 1000 & 11,549 & 3000 & 205,862 & & & & \\
\hline
\end{tabular}

For a given value of the electrolyser-rated power, the hydrogen production cost can be calculated according to Eq. (1) when the following variables are known: the size of the storage and compression devices, the annual amount of electricity fed into the system, the annual hydrogen production and (eventually) the annual oxygen production. By repeating this calculation for a total of 15-20 values of the electrolyser-rated power, it is possible to obtain the hydrogen production cost curve. The results for each sub-

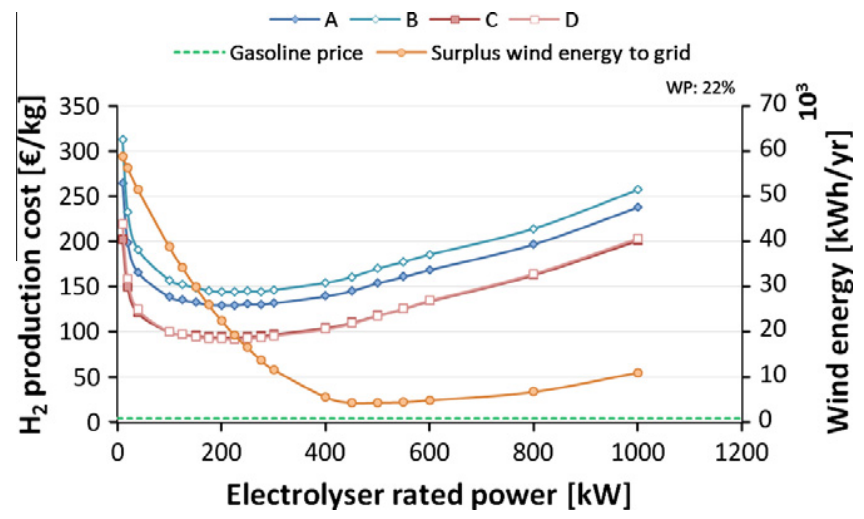

Fig. 10. Hydrogen production cost compared to gasoline price (WP: 22\%).

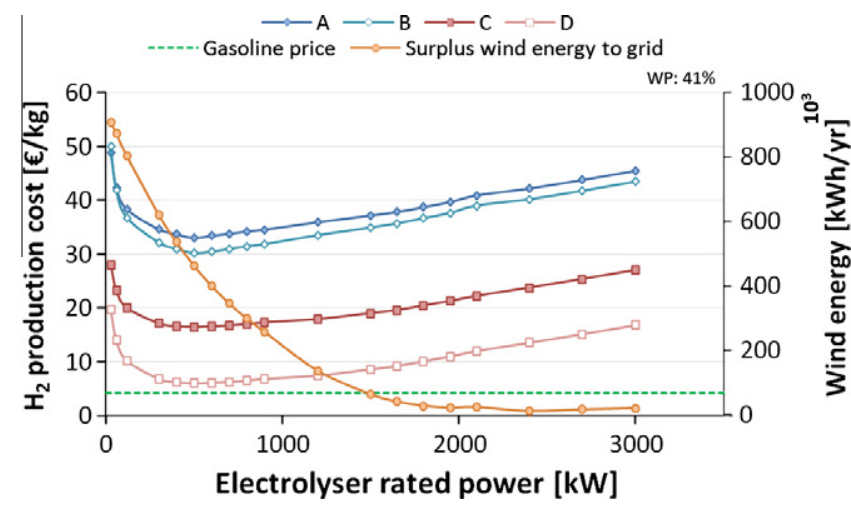

Fig. 11. Hydrogen production cost compared to gasoline price (WP: 41\%). case and for each WP value investigated in the study are displayed in Figs. 10-13, in which the curves of hydrogen production cost are compared with the gasoline price and with the amount of the annual surplus of wind energy not usable for producing hydrogen and therefore fed into the grid and delivered to remote users. The gasoline price refers to $3.84 \mathrm{~L}$ of fuel, because this volume of fuel contains the same amount of energy as $1 \mathrm{~kg}$ of hydrogen.

It must be noted that the "surplus wind energy to grid" is the sum of the two fractions that are not useful to produce hydrogen

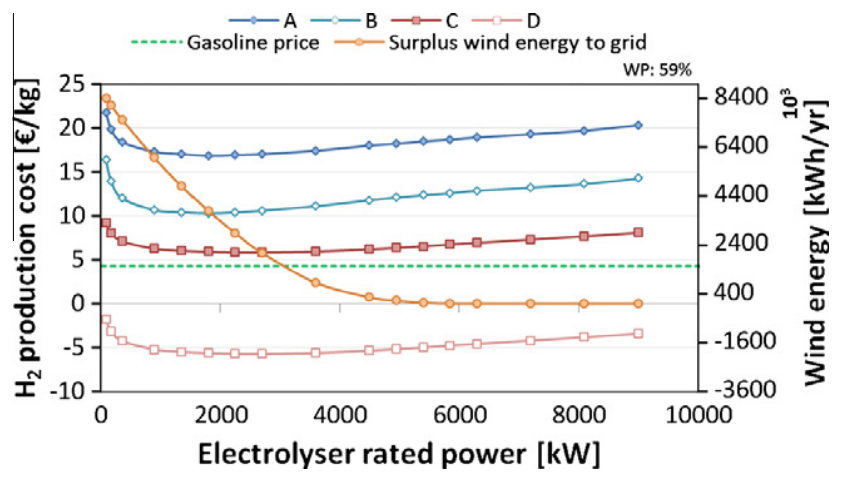

Fig. 12. Hydrogen production cost compared to gasoline price (WP: 59\%).

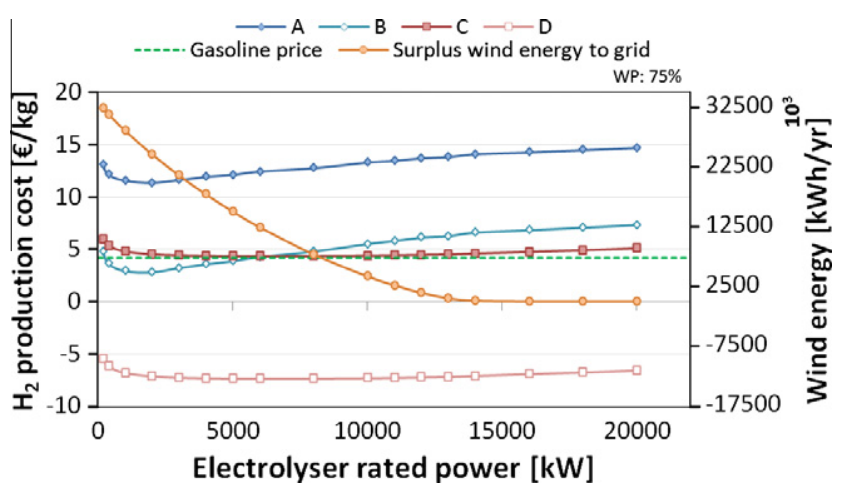

Fig. 13. Hydrogen production cost compared to gasoline price (WP: 75\%). 
because the power is higher than the electrolyser-rated power or lower than its idling threshold.

The hydrogen production cost generally decreases when the WP increases, if we assume that the oxygen is sold (sub-cases B and D), or if we assume the storage section is removed (sub-cases $C$ and D). Only when the WP is $22 \%$ do we observe a different result: the hydrogen production cost increases from sub-case A to sub-case $B$. In other words, the annual costs associated with the oxygen storage and the compression devices are higher than the revenue from the sale of the oxygen produced throughout the year. This observation is mainly due to the low productivity of the electrolyser, which operates with a maximum capacity factor of $2.2 \%$.

Negative values of the hydrogen production cost can be observed for the higher WPs, such as the case in which we assume that the oxygen is sold and remove the storage section (sub-case D). This occurs because the income from selling oxygen is higher than total annual costs.

The hydrogen is competitive with gasoline only in sub-case D and for WPs higher than $50 \%$.

The minimum point of the hydrogen production cost curve never matches the minimum point of the curve associated with the surplus wind energy not used to produce hydrogen. In other words, the economic and energetic optimums do not coincide in any of the sub-cases that we investigated. However, for the higher WPs (especially in sub-cases $C$ and D), the peak-shaving effect can be maximised with a small increase in the hydrogen production cost by moving from the economic to the energetic optimum.

To better analyse the option of using hydrogen as a fuel for vehicles, we considered two additional cases:

i. Hydrogen for public transportation.

ii. Hydrogen for private transportation.

In both cases, we estimated the annual potential hydrogen demand associated with a fleet of vehicles for the regional context under examination.

To assess the vehicle consumption for public transportation, we used the hydrogen consumption figures provided by the CUTE project [52], which are based on a Mercedes-Benz Fuel Cell Citaro city bus. We also used the data collected from Ref. [53] on the buses operating in Sicily and on the average distance covered per bus (Table 9).

Using the figures from Table 9, we obtained the annual hydrogen demand associated with a single bus and the size of the bus fleet serving the entire population analysed in the study (Table 10).

In the second case, we used the technical specifications of the HONDA FCX-Stack [54], the average distance covered per car [55] and the number of cars per inhabitants in Italy [56] (Table 11).

Using the data listed in Table 11, we assessed the annual hydrogen demand associated with a single private car and the size

Table 9

Preliminary data for estimating the hydrogen demand for public transportation.

$\begin{array}{ll}\text { Average hydrogen consumption per bus }\left(\mathrm{kg} \mathrm{H}_{2} / \mathrm{km}\right) & 0.246 \\ \text { Average distance covered per bus (Sicily) }(\mathrm{km} / \mathrm{yr}) & 36,946 \\ \text { Buses operating in Sicily } & 3107 \\ \text { Sicily population (inhabitants) } & 4,968,991 \\ \text { Population investigated in this study (inhabitants) } & 20,000\end{array}$

Table 10

Hydrogen demand for public transportation.

\begin{tabular}{ll}
\hline Buses per inhabitant & 0.000625278 \\
Annual $\mathrm{H}_{2}$ demand per bus (kg/yr) & 9089 \\
Size of the bus fleet (vehicles) & 13 \\
\hline
\end{tabular}

Table 11

Preliminary data for estimating the hydrogen demand for private transportation.

\begin{tabular}{ll}
\hline Fuel & Hydrogen gas \\
\hline Technical specifications of the HONDA - FCX Stack & \\
Pressure of storage (MPa) & 35 \\
Tank capacity (L) & 157 \\
Fuel cell stack power output $\left(\mathrm{kW}_{\mathrm{el}}\right)$ & 86 \\
Top speed $(\mathrm{km} / \mathrm{h})$ & 150 \\
Range, consumption $(\mathrm{km})$ & 430 \\
Other preliminary data & \\
Average distance covered per car $(\mathrm{km} / \mathrm{yr})$ & 15,000 \\
Cars per inhabitants in Italy & 0.747 \\
Population investigated in this study (inhabitants) & 20,000 \\
\hline
\end{tabular}

Table 12

Hydrogen demand for private transportation.

\begin{tabular}{ll} 
Tank capacity $\left(20^{\circ} \mathrm{C}\right)(\mathrm{kg})$ & 4.57 \\
Hydrogen consumption per car $(\mathrm{kg} \mathrm{H} / \mathrm{km})$ & 0.011 \\
Annual $\mathrm{H}_{2}$ demand per car $(\mathrm{kg} \mathrm{H} / \mathrm{yr})$ & 159 \\
Size of the private car fleet (vehicles) & 14,940 \\
\hline
\end{tabular}

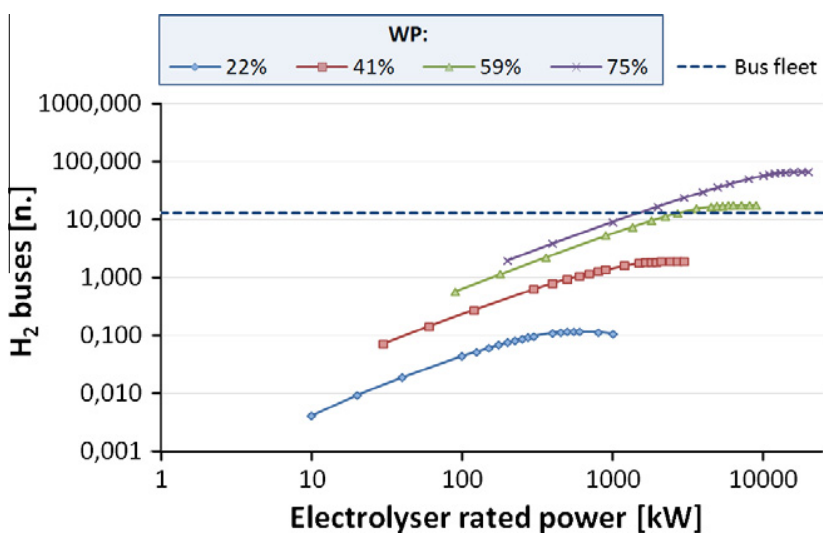

Fig. 14. Wind-hydrogen for public transportation: number of $\mathrm{H}_{2}$ buses as a function of WP and electrolyser-rated power.

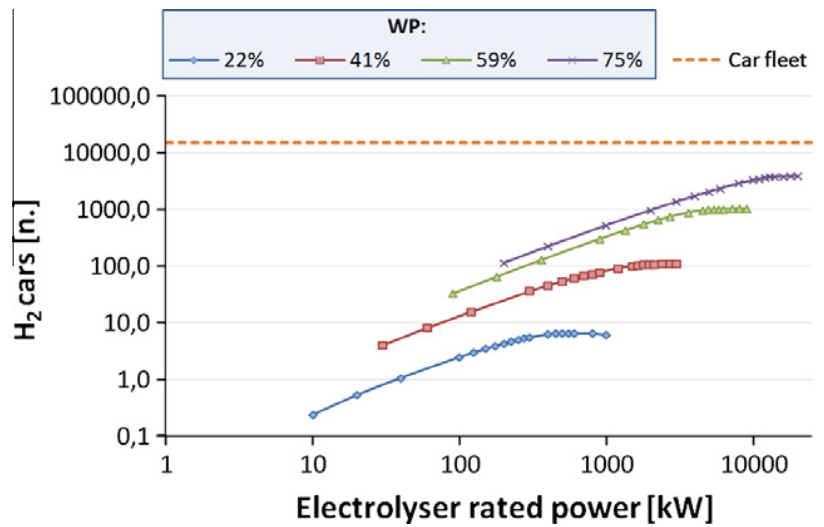

Fig. 15. Wind-hydrogen for private transportation: number of $\mathrm{H}_{2}$ cars as a function of WP and electrolyser-rated power.

of the private car fleet used by the entire population investigated in the study (Table 12).

Figs. 14 and 15 show a comparison for each WP between the number of vehicles (buses and private cars, respectively) that can be fuelled with the hydrogen produced annually from wind power and the size of the vehicle fleet serving the entire population. 
The hydrogen demand for public transportation can be fully met only for the cases related to the highest WPs (59\% and 75\%), whereas the hydrogen demand for private transportation cannot be entirely satisfied in any case.

If we assume a WP of $22 \%$, the low production volumes and the high production cost of hydrogen make the wind-hydrogentransportation chain an unsuitable solution. By increasing the WP from $22 \%$ to $41 \%$, the annual hydrogen production becomes more highly significant, but the hydrogen production cost is still too high for economic gain. In this case, the wind-hydrogen integration can be justified by placing the electrolytic products on the industrial gas market.

The wind-hydrogen-transportation chain becomes economically sustainable when the WP is greater than $60 \%$, the storage section is drastically reduced (or not considered) and the oxygen is sold on the market. Under these conditions, the hydrogen production cost is comparable to or lower than the gasoline price, and the hydrogen production volumes are high enough to cover the entire (or almost the entire) annual demand for public transportation or a significant portion of the annual demand for private transportation.

\subsection{Case 2 - Hydrogen for stationary use}

In this case, the hydrogen plant includes a fuel-cell generator in addition to the electrolyser and the storage and compression units. For a given value of the electrolyser-rated power, the fuel cell is sized using an iterative optimisation process. This iterative optimisation process has been developed directly in TRNSYS to identify the fuel-cell size that minimises the gap between the hydrogen production and demand according to the fuel-cell physical model implemented in the HYDROGEMS library.

In contrast to Case 1, the time-profile of the hydrogen demand in this case cannot be assumed as constant because it depends on how and when the fuel cell generator is operated. Moreover, because the hydrogen is produced when the fuel cell generator does not operate, a larger storage section is required to balance the hydrogen production and the consumption.

The time profile of the annual oxygen demand is assumed to be constant.

The electricity delivered by the fuel cell generator is directly supplied to the user. The contribution of the fuel cell generator to the total electricity demand depends on the annual hydrogen production and increases with the size of the electrolyser and with the WP, as shown in Figs. 16-19.

For the lower WPs, the impact of the fuel cell generator on the total electricity demand is insignificant. The windhydrogen-electricity chain makes greater economic sense when the WP is higher than $50 \%$.

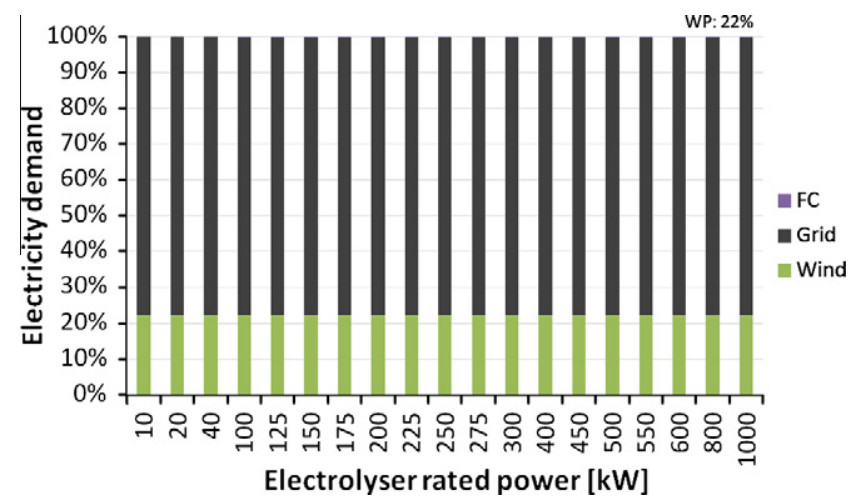

Fig. 16. Contributions to the total electricity demand as a function of the electrolyser-rated power (WP: $22 \%$ ).

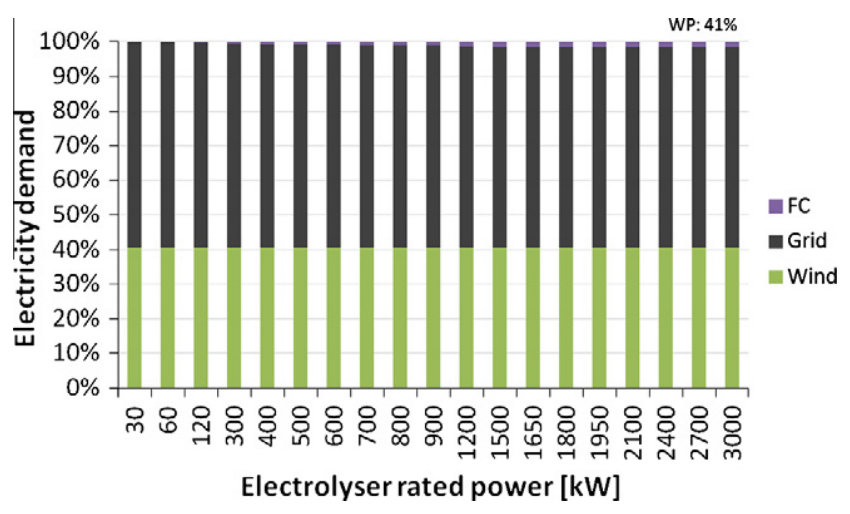

Fig. 17. Contributions to the total electricity demand as a function of the electrolyser-rated power (WP: 41\%).

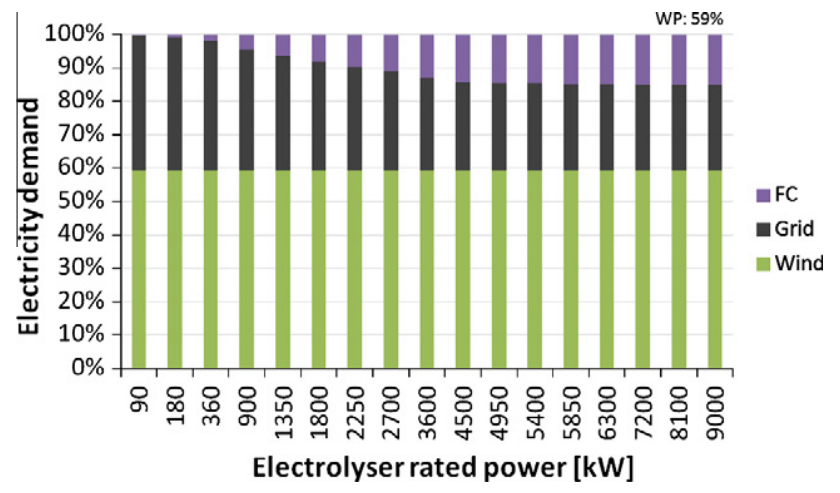

Fig. 18. Contributions to the total electricity demand as a function of the electrolyser-rated power (WP: 59\%).

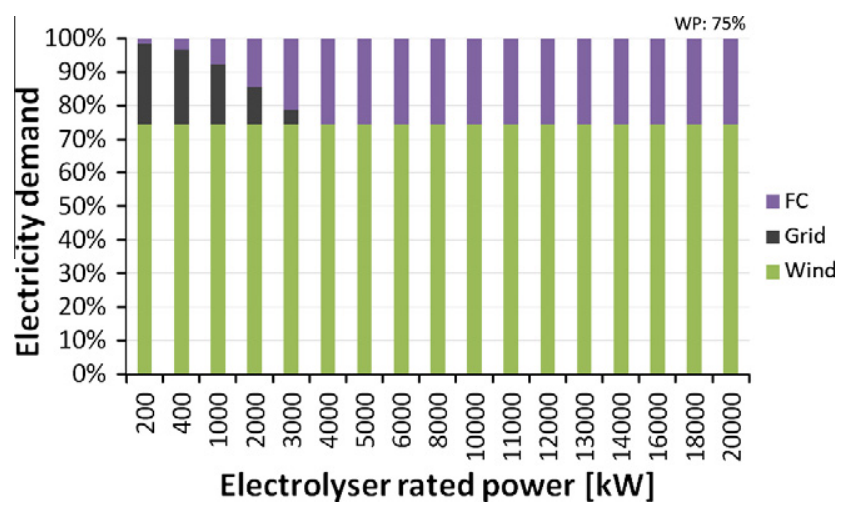

Fig. 19. Contributions to the total electricity demand as a function of the electrolyser-rated power (WP: 75\%).

When we assume a WP of 75\%, the surplus wind energy available to produce hydrogen is high, and we find that a 4-MW electrolyser and a 6-MW fuel cell generator are sufficient to cover the remaining $25 \%$ of the electricity demand. Consequently, if we increase the size of the electrolyser (maintaining a constant size of the fuel cell generator), then a surplus of hydrogen arises. This surplus hydrogen can be used in a variety of applications in the energy and industrial sectors. Fig. 20 shows a comparison between the number of vehicles (buses and private cars) that can be fuelled on an annual basis with the surplus hydrogen produced by installing electrolysers larger than $4 \mathrm{MW}$ and the size of the vehicle fleet serving the community investigated in the study. 


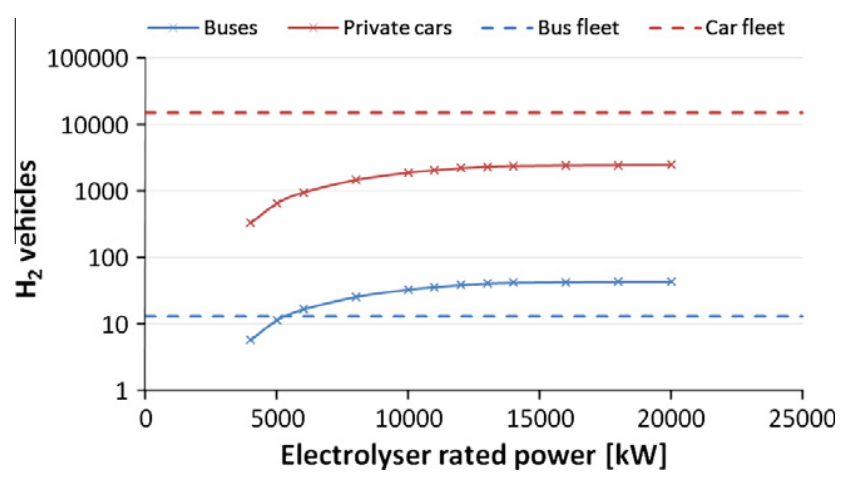

Fig. 20. Surplus hydrogen for public and private transportation.

An electrolyser larger than $5 \mathrm{MW}$ is able to meet the total hydrogen demand for public transportation and a significant portion of the hydrogen demand for private transportation but not greater than $20 \%$ of the demand for private transportation.

\section{Conclusion}

Wind-hydrogen integration is a promising approach to support the deployment of wind energy in the electricity supply systems.

This paper presents a study of the use of wind power that is not matched with hourly electricity demand to produce hydrogen via electrolysis as a strategy to mitigate the negative impacts due to wind farm operation in a high-wind-energy penetration power system. The sizes of the hydrogen production and storage devices have been optimised using a specific analytical method that can be applied to any wind-hydrogen grid-connected system. The accuracy of this method depends upon the accuracy and reliability of the initial data and the costs and lifetimes of the devices included.

In general, the economic and business feasibility of a windhydrogen system depends on many other factors not considered in the study, such as the policy, tariff and regulatory aspects of renewable power generation. The optimisation method suggested in this work can be a useful starting tool for the further development of business plans for wind-hydrogen power systems and gives useful information regarding the design criteria and the production cost of the hydrogen in such applications.

As a result of the study, hydrogen production by electrolysis has been confirmed as a valuable option for reducing the amount of surplus wind power fed into the grid in the off-peak periods.

In each of the cases analysed, the hydrogen plant configuration that minimised the hydrogen production cost was not the same as the plant configuration that minimised the annual amount of surplus wind energy fed into the grid.

The wind-hydrogen-transportation chain (Case 1) makes sense only for the higher WPs due to the corresponding high annual hydrogen production. The wind-hydrogen-transportation chain is more feasible if the storage section is reduced as much as possible, and the electrolytic oxygen is sold to the market to reduce the hydrogen production cost.

In Case 2 (hydrogen for stationary use), a relatively large storage section is required because the hydrogen production and consumption are time-decoupled. This scenario makes the reduction of the hydrogen production cost difficult to put into practice (mainly for the higher WPs).

For a given WP, a hydrogen plant larger than that corresponding to the economic optimum yields both advantages and disadvantages. The major advantages include an increase in the peakshaving effect and a larger amount of hydrogen produced annually for use as a fuel for transportation or for electricity generation. The disadvantages include a higher hydrogen production cost and a lower capacity factor for both the electrolyser and fuel cell generator. Each of these aspects can play a major role in hydrogen plant construction.

\section{References}

[1] Holttinen H. Estimating the impacts of wind power on power systems summary of IEA wind collaboration. Environ Res Lett 2008;3(April 28):025001 (6p).

[2] Holttinen H, Lemström B, Meibom P, Bindner H, Orths A, van Hulle F, et al. Design and operation of power systems with large amounts of wind power state of the art report. IEA WIND Task 25; October 2007. <http:// www.ieawind.org/AnnexXXV/Publications/W82.pdf>.

[3] Georgilakis PS. Technical challenges associated with the integration of wind power into power systems. Renew Sustain Energy Rev 2008;12:852-63.

[4] UCTE. Integrating wind power in the European power systems - prerequisites for successful and organic growth. Position Paper; May 2004.

[5] Gonzàlez A, McKeogh E, Ó Gallachóir B. Hydrogen production from wind energy in the Irish scenario. In: Proceedings of the 1st European hydrogen energy conference, Grenoble, France; September 02-05, 2003.

[6] Gonzàlez A, McKeogh E, Gallachóir BÓ. The role of hydrogen in high wind Energy penetration electricity systems: the Irish case. Renew Energy 2003:29:471-89.

[7] Sherif SA, Barbir F, Veziroglu TN. Wind energy and the hydrogen economy review of the technology. Sol Energy 2005;78:647-60.

[8] Korpås M, Greiner C]. Opportunities for hydrogen production in connection with wind power in weak grids. Renew Energy 2008;33:1199-208.

[9] Mantza RJ, De Battista H. Hydrogen production from idle generation capacity of wind turbines. Int J Hydrogen Energy 2008;33:4291-300.

[10] Jørgensen C, Ropenus S. Production price of hydrogen from grid connected electrolysis in a power market with high wind penetration. Int J Hydrogen Energy 2008;33:5335-44.

[11] Shaw S, Peteves E. Exploiting synergies in European wind and hydrogen sectors: a cost-benefit assessment. Int J Hydrogen Energy 2008;33:3249-63.

[12] Linnemann J, Steinberger-Wilckens R. Realistic costs of wind-hydrogen vehicle fuel production. Int J Hydrogen Energy 2007;32:1492-9.

[13] Greiner CJ, Korpås M, Holen AT. A Norwegian case study on the production of hydrogen from wind power. Int J Hydrogen Energy 2007;32:1500-7.

[14] Pelacchi P, Poli D. The influence of wind generation on power system reliability and the possible use of hydrogen storages. Electr Power Syst Res 2010;80: 249-55.

[15] Bernal-Agustín JL, Dufo-López R. Hourly energy management for gridconnected wind-hydrogen systems. Int J Hydrogen Energy 2008;33:6401-13.

[16] Gutiérrez-Martìn F, Confente D, Guerra I. Management of variable electricity loads in wind-hydrogen systems: the case of a Spanish wind farm. Int J Hydrogen Energy 2010;35:7329-36.

[17] Rodrìguez F, Riso M, Jiménez Yob G, Ottogalli R, Santa Cruz R, Aisa S, et al. Analysis of the potential for hydrogen production in the province of Córdoba, Argentina, from wind resources. Int J Hydrogen Energy 2010;35:5952-6.

[18] Troncoso E, Newborough M. Electrolysers for mitigating wind curtailment and producing 'green' merchant hydrogen. Int J Hydrogen Energy 2011;36:120-34.

[19] Dutton AG, Bleijs JAM, Dienhart H, Falchetta M, Hug W, Prischich D, et al. Experience in the design, sizing, economics, and implementation of autonomous wind-powered hydrogen production systems. Int J Hydrogen Energy 2000;25:705-22.

[20] Bergen A, Pitt L, Rowe A, Wild P, Djilali N. Transient electrolyser response in a renewable-regenerative energy system. Int J Hydrogen Energy 2009;34: 64-70.

[21] Klein SA, Beckman WA, Mitchell JW, Duffie JA, Duffie NA, Freeman TL, et al. TRNSYS 16 manual. Mathematical reference, vol. 5. Madison, Wisconsin, USA: Solar Energy Laboratory (SEL), University of Wisconsin-Madison; 2005.

[22] HOMER energy modeling software. <http://www.homerenergy.com/>.

[23] Centre for Renewable Energy Sources (Greece), Institute for Energy Technology (Norway), Trama Tecno Ambiental (Spain), Econnect Limited (UK). Market Potential Analysis for Introduction of Hydrogen Energy Technology in StandAlone Power Systems. Technology report H-SAPS, ALTENER Progr.; 2004.

[24] Mann MK, Spath PL, Amos WA. Technoeconomic analysis of different options for the production of hydrogen from sunlight, wind and biomass. In: Proceedings of the 1998 US DOE hydrogen program, review; 1998.

[25] Berry GD. Hydrogen as a transportation fuel: costs and benefits. Lawrence Livermore nation. Labor. UCRL-ID-123465; March 1996. <http:// www.osti.gov/bridge/servlets/purl/230382-aXfCXH/webviewable/ 230382.PDF>.

[26] Carlsson P, Grondalen O, Steinwall P, Svensson J. Executive summary of feasibility study, automated solar-hydrogen-fuel-cell autarkic electricity supply system ASHFAES. Presented at the 1998 study group on hydrogen and working committee 2 executive meeting of the international gas union; May 1998.

[27] Andreassen K. Hydrogen production by electrolysis. In: Hydrogen power: theoretical and engineering solutions. Dordrecht, Netherlands: Kluwer Academic Publishers; 1998. p. 91-102. 
[28] Ogden JM, DeLuchi MA. Renewable hydrogen transportation fuels. In: The 9th world hydrogen energy conference; March 13, 1992. Draft for June 1992 Conference.

[29] Nelson DB, Nehrir MH, Wang C. Unit sizing and cost analysis of stand-alone hybrid wind/PV/fuel cell power generation systems. Renew Energy 2006;31:1641-56.

[30] Norsk Hydro. Personal communications; November 2007-February 2008

[31] Howes J. The potential for renewable hydrogen as a transport fuel for the UK Thesis, Imperial College of Science, Technology and Medicine, Faculty of Life Sciences, University of London, Department of Environmental Science \& Technology, London, UK; September 2002.

[32] Padró CEG, Putsche V. Survey of the economics of hydrogen technologies. Technical report NREL/TP-570-27079; September 1999. <http://www1.eere. energy.gov/hydrogenandfuelcells/pdfs/27079.pdf>.

[33] Thomas CE, Kuhn Jr IF. Electrolytic hydrogen production infrastructure options evaluation. Final subcontract report NREL/TP-463-7903; September 1995. <www.osti.gov/bridge/servlets/purl/125028-MGPbw5/webviewable/ 125028.PDF>.

[34] Oy N. New hydrogen technologies project report: evaluation of techniques, Finland; 1992

[35] Taylor JB, Alderson JEA, Kalyanam KM, Lyle AB, Phillips LA. A technical and economic assessment of methods for the storage of large quantities of hydrogen. Int J Hydrogen Energy 1986;11:5-22.

[36] Amos WA. Costs of storing and transporting hydrogen. Report NREL/TP-57025106; November 1998. <http://www1.eere.energy.gov/hydrogenandfuelcells/ pdfs/25106.pdf>.

[37] Tzimas E, Filiou C, Peteves SD, Veyret JB. Hydrogen storage: state of the art and future perspective. Scientific and technical research series EUR 20995 EN Europ. Commission, Institute for Energy; 2003. <http://ie.jrc.ec.europa.eu/ publications/scientific_publications/2003/P2003-181=EUR20995EN.pdf >

[38] Syed MT, Sherif SA, Veziroglu TN, Sheffield JW. An economic analysis of three hydrogen liquefaction systems. Int J Hydrogen Energy 1998;23:565-76.

[39] Oi T, Wada K. Feasibility study on hydrogen refueling infrastructure for fue cell vehicles using the off-peak power in Japan. Int J Hydrogen Energy 2004;29:347-54.

[40] Gerrard AM. Guide to capital cost estimating. 4th ed. Rugby, UK: Institution of Chemical Engineers; 2000. ISBN: 0-85295-399-2.

[41] Da Silva EP, Marin Neto AJ, Ferreira PFP, Camargo JC, Apolinàrio FR, Pinto CS. Analysis of hydrogen production from combined photovoltaics, wind energy and secondary hydroelectricity supply in Brazil. Sol Energy 2005;78: $670-7$.
[42] Cotrell J, Pratt W. Modeling the feasibility of using fuel cells and hydrogen internal combustion engines in remote renewable energy systems. Technical report NREL/TP-500-34648; September 2003. <http://www.nrel.gov/docs/ fy03osti/34648.pdf>.

[43] Pratt W. A preliminary investigation of two small-scale, autonomous windhydrogen systems. NREL, NWTC, TRAC Program, Boulder, Colorado, USA; August 2002

[44] Smith AFG, Newborough M. Engineering and physical sciences (Heriot-Watt University, Edinburgh, Scotland, UK). Low-cost polymer electrolyzers and electrolyzer implementation scenarios for carbon abatement. Report to the carbon trust and ITM-Power PLC; 2004.

[45] Levene JI, Mann MK, Margolis RM, Milbrandt A. An analysis of hydrogen production from renewable electricity sources. Sol Energy 2007;81:773-80.

[46] Praxair. Personal communication; March 2008.

[47] Terna - rete elettrica nazionale S.p.A. dati statistici sull'energia elettrica in Italia; 2007. <http://www.terna.it/Default.aspx?tabid=418>

[48] Terna - rete elettrica nazionale S.p.A. <http://www.terna.it/>.

[49] Bivona S, Burlon R, Leone C. Hourly wind speed analysis in Sicily. Renew Energy 2003;28:1371-85.

[50] Lambert T, Gilman P, Lilienthal P. Micropower system modeling with HOMER. In: Farret $F$, Simões $M$, editors. Integration of alternative sources of energy. Hoboken, New Jersey, USA: John Wiley and Sons, Inc.; 2006. p. 379-416. ISBN 0-471-71232-9.

[51] Lambert T. HOMER Help. In: HOMER Version 2.2 beta. Last modified May 26, 2004.

[52] CUTE, Clean Urban Transport for Europe. The future of transportation is clean. Dissemination of results after two years in practice. <http://cute-hamburg. motum.revorm.com>.

[53] Pagliaro L, Alamia V, Flaccomio G, Mesiti A. Relazione sull'indagine relativa al sistema del trasporto pubblico locale in Sicilia. Corte dei Conti - Sezione di controllo per la Regione Siciliana. Palermo, Italia: Giugno; 2003. <http:// www.regione.sicilia.it/turismo/trasporti/arcdocumenti/2003/ indagine\%20corteconti\%20TPL\%202003.pdf>

[54] Netinform - the service portal of TÜV SÜD industrie service GmbH. FCX (Honda Stack). Prototype vehicle; 2004. <http://www.netinform.net/H2/ H2Mobility/H2MobilityMain.aspx?ID=84\&CATID=1>.

[55] Automobile Club d'Italia (ACI), EURISPES. Rapporto sulla qualità della mobilità nelle province italiane. Roma, Italia; 13 Settembre, 2006. <http://www.aci.it/ fileadmin/documenti/SintesiRapportoMobilita.pdf $>$.

[56] Automobile Club d'Italia (ACI). Annuario statistico 2007 - Capitolo 3 - Consistenza parco veicoli - Tables III.1-III.32; 2007. <http://www.aci.it/index.php?id=2085>. 